\title{
Ylevä ja muuttumaton vai arkinen ja muuttuvainen?
}

John Dewey: Filosofian uudistaminen (2012). Suom.

Tuukka Perhoniemi. Vastapaino. 233 s. (Reconstruction in

Philosophy, 1920). ISBN 978-951-768-317-3.
PRAGMATISMI SYNTYI Bostonin Harvardissa 1870-luvulla ja sen tunnetuimpia edustajia olivat John Deweyn lisäksi C.S. Peirce, William James, G.H. Mead ja C. I. Lewis. Filosofian historiaa tuntevan Deweyn mukaan pragmatismi on vain uusi nimi vanhoille asioille. Viime vuosina niin sanotun käytäntökäänteen myötä (practice turn) monet pragmatistien ajatukset ovat tulleet uudella tavalla filosofien ja yhteiskuntatieteilijöiden keskusteluun.

Filosofian uudistaminen syntyi luentojen perusteella, jotka Dewey (1859-1952) piti Tokion keisarillisessa yliopistossa. Lähtökohtana on teesi, jonka mukaan ajattelu ei voi olla itseriittoista, vaan sen tarkoituksena on toiminnan ohjaaminen. Deweylle filosofia on loputtoman kyseenalaistamisen tie, jossa filosofit ovat Jyri Aleniuksen sanoin "enemmän hovinarreja kuin älyllistä papistoa".

Filosofian uudistaminen vaikuttaa konkreettisesti, ei käsitteiden hienosäätöihin. Kun halutaan tietää jotain, olevaisen perimmäisen luonteen pohdinta ei riitä, vaan asioita on tutkittava käytännössä ja kokeiltava erilaisia ratkaisuvaihtoehtoja. Filosofia löytää voimansa, kun se lakkaa olemasta väline filosofien ongelmien käsittelyyn ja muuttuu filosofien kehittelemäksi menetelmäksi ihmisten ongelmien käsittelyyn.

Vaikka antiikin Kreikassa mekaniikka ja geometria edistyivät, varsinaista käytännön tietoa hankkivat statukseltaan alhaiset henkilöt eli orjat ja käsityöläiset. Niinpä myös käytännössä saatu ongelman ratkaisuun suuntautuva tieto oli statukseltaan alhaista. Käytäntöön ja muuttuvaisuuteen liittyy aina epävarmuus, mutta muuttumattomuuteen liittyvät arjen ylittävät ikuiset olemukset. Klassisen filosofian tehtäväksi tuli paljastaa muuttumaton ja ennalta annettu todellisuus kaiken muuttuvan ja epäolennaisen takana. Myöhemmässä teoksessaan Dewey esittää asian napakasti:

"Jos tutkii Platonin ja Aristoteleen filosofian perustaa samaan tapaan kuin antropologi tarkastelee aineistoaan, siis kulttuurin osana, on selvää, että nämä filosofiat rationalisoivat systemaattisessa muodossa kreikkalaisten uskonnollisten ja taiteellisten $k a ̈$ sitysten sisällön." (Dewey: The Quest for certainty, 1929/ Pyrkimys varmuuteen, 1999.)

\section{PUHTAAN AJATTELUN VERKKO}

Deweyn mukaan Ihmismieli olettaa spontaanisti, että ilmiöt ovat yksinkertaisempia ja yhtenäisempiä kuin ne ovatkaan. Mieli tekee pinnallisia analogioita, jättää monimutkaisuuden ja poikkeukset huomiotta ja "punoo puhtaasti ajattelusta koostuvan verkon, jonka se langettaa luonnon ylle" (Filosofian uudistaminen, s. 78). Kun tiede ja filosofia koostuivat luontoa koskevista odotuksista, kumpikin antoi luonnolle vääränlaisen rationaalisen pelkistyksen. Samaan tapaan Michel Foucault väittää, ettei tiede 1600-luvun alussa edennyt siksi, että se olisi opettanut katsomaan läheltä ja tarkoin, vaan koska havaintoja opittiin pelkistämään ja luokittelemaan.

Kun tieto kumuloitui johdonmukaisesti, ahkerasti opiskele- 
van oli mahdollista oppia kaikki tietämisen arvoinen. Vuoteen 1327 sijoittuvassa Umberto Econ Ruusun nimi -romaanissa noviisimunkki Adso toteaa opettajansa William Baskervillen, entisen inkvisition jäsenen, tietävän kaiken. Baskerville vastaa, ehkä hivenen ironisesti, että jos hän tosiaan tietäisi kaiken, hän olisi Pariisin yliopistossa opettamassa teologiaa.

Käytännön, läheltä katsomisen ja muuttuvaisuuden välttely eivät jää vaille yhteiskunnallisia ja poliittisia seurauksia. Kun keskustellaan "olemuksista", kuten yksilöstä, valtiosta tai instituutiosta yleensä, ei keskustella käytännön ongelmista tai ongelmien ratkaisuista. Metafyysinen oppi pysyvästä ja universaalista erityisen ja muuttuvan kustannuksella oikeutti Deweyn mukaan kunkin ajan poliittisen ja kirkollisen järjestyksen. Saksalainen idealismi puolusti status quota Ranskan vallankumouksen radikaaleja oppeja vastaan. Hegelin oppi valtiosta pyhitti Preussin valtiokoneiston ja byrokratian. "Pääoma ja työvoima eivät voi 'todella' olla ristiriidassa keskenään, sillä kumpikin on toisen orgaaninen välttämättömyys - - Mitään sukupuolten välistä ongelmaa ei voi 'todellisuudessa' olla, sillä miehet ja naiset ovat ehdottoman välttämättömiä toisilleen ja valtiolle." (Filosofian uudistaminen, s. 205).

\section{HYVÄ ON KOMMUNIKOITAVAA}

\section{JA JAETTAVAA}

Pragmatistit haluavat purkaa turhina ja haitallisina näkemiään jokotai-tyyppisiä dikotomioita, kuten yksilö vs. yhteiskunta, järki vs. tunne tai arvot vs. tosiasiat. Dewey, samoin kuin Richard Rorty 1970-luvulla, halusi purkaa myös mielen ja ruumiin dikotomian ja sekä Dewey että Rorty esittivät, että mielen ja ruumiin suhteesta käytävät loputtomat väittelyt johtuvat usein vain käsitteellisistä sekaannuksista.

Jyrkkä ja ehdoton ei voi myöskään olla moraalisen toiminnan erottelu päämääriin ja keinoihin. Päämäärien ja keinojen kutoutuminen jokapäiväiseen elämään tekee arvokkaat asiat toimiviksi. Kun älylliset kysymykset ovat moraalisia, myös naturalismin ja humanismin kahtiajako suhteellistuu. Erilaiset luokittelun perusteet voivat olla yhtä päteviä, kun pidetään mielessä erilaiset päämäärät.

Dewey jäljittää eettisen teorian synnyn antiikin kreikkalaisten yritykseen löytää käyttäytymisen sääntelylle järjellinen perusta ja tarkoitus sen sijaan, että ne olisi johdettu perinteistä. Järki perinteen korvaajana piti kuitenkin asiat yhtä muuttumattomina kuin perinnäistavat. Etiikan tehtävänä on siitä pitäen ollut jonkin viimekätisen päämäärän tai lain perusteen löytäminen, kuten uskollisuus jumalalliselle tai maalliselle auktoriteetille. Kuitenkin tilanteet ovat ainutkertaisia ja ristiriitaisia, ja harkinnan ja vastuullisten valintojen tuella on löydettävä juuri tähän tilanteeseen sopiva hyvä.

Kun moraalifilosofit ovat pitäneet tavoiteltavaa hyvää jonakin yleispätevänä ja objektiivisena Platon metafyysisenä universaalina, Kant loogisena universaalina - hyvä on harvemmin nähty yk- sityisenä ja yksittäisenä tapahtumisena.

Moral theory and practice -artikkelissaan Dewey esitti jo vuonna 1891: "... a man has not to do Justice and Love and Truth; he has to do justly and truly and lovingly."

Deweyn mukaan jokainen itsessään hyvä asia on ainutkertainen ja voi todentua vain kommunikaatiossa, jakamisessa ja yhteisessä osallisuudessa. Tilanne, jossa hyvä tiedostetaan, ei ole ohimenevä aistimus tai yksityinen halu, vaan julkinen, sosiaalinen ja jaettu. Hyvän jaettavuus ja kommunikoitavuus myös pelastaa moraalin moralisoinnilta ja paremmin tietämiseltä.

Deweyn ajatukset tuntuvat hyvin tuoreilta. Suomennos säilyttää tekstin imun hyvin. Jossittelua unohtamatta: olisi ehkä sittenkin hyvä, elleivät Deweyn ja muiden pragmatistien ajatukset tuntuisi aivan näin tuoreilta. Tällöin ohuiden abstraktioiden toiminnallistaminen ja dikotomioiden suhteellistaminen tai monimutkaisuuden ja yhteiskuntakriittisyyden painotukset olisivat olleet kauemmin ja painokkaammin osa suomalaista ajattelun maisemaa.

\section{Jussi Onnismaa}

dosentti, työnohjaajakouluttaja Helsingin yliopisto, Palmenia 